\title{
Reconsidering the 'Decline' of Dental Student Empathy within the Course in Latin America
}

\section{Reconsiderando o 'Declínio' da Empatia com o Curso em Estudantes de Odontologia na América Latina}

\author{
Víctor Patricio DÍAZ-NARVÁEZ $\triangle^{1,2}$, Ana María Erazo CORONADO ${ }^{3}$, Jorge Luis BILBAO4 ${ }^{4}$, Farith GONZÁLEZ ${ }^{5}$, \\ Mariela PADILLA ${ }^{6}$, Aracelis CALZADILLA-NUÑEZ ${ }^{7}$, María Guadalupe SILVA-VETRI ${ }^{8}$, Joel ARBOLEDA ${ }^{9}$, \\ Mirian BULLEN ${ }^{10}$, Robert UTSMAN ${ }^{11}$, Elizabeth FAJARDO ${ }^{12}$, Luz Marina ALONSO ${ }^{13}$, Marcos CERVANTES ${ }^{14}$, \\ Teresa VARELA ${ }^{15}$ \\ Acta Med Port 2017 Nov;30(11):775-782 - https://doi.org/10.20344/amp.8681
}

\section{ABSTRACT}

Introduction: The controversy over the presence of empathic decline within the course in students of medicine, dentistry and health sciences in general, has not fully been studied. This controversy could be partially solved if massive studies of empathy levels are made in similar cultural, social and economic contexts.

Material and Methods: Empathy levels within the course were studied in eighteen dental schools from six countries in Latin America (2013). The mean of the empathy levels were used to study the behavior between first and fifth academic years. The values of empathy levels within the course were observed by applying the Jefferson Scale of Physician Empathy, the Spanish version. All these studies were cross-sectional. The value of means observed, were subjected to regression studies and further adjustment curves were obtained and the coefficient of determination were calculated.

Results: Six different models of behavior were observed, which found that five of them suffer empathic decline within the course, but with different final results: in some the decline persists until the fifth academic year and in others, this decline 'recovers' persistently until the fifth academic year. The sixth model is characterized by a constant and persistent increase of levels of empathy within the course until the last academic year.

Discussion: There are six different models for the behavior of means of levels of empathy within the course evaluated by a common methodology in eighteen dental schools from six countries of Latin America. These findings support the existence of variability of empathic response and a comprehensive approach is needed to find the causes that give rise to this variability.

Conclusion: In dental students of Latin America, there is variability in the behavior of the distribution in means between the academic years of the dentistry schools examined in this study.

Keywords: Empathy; Latin America; Students, Dental/psychology

\section{RESUMO}

Introdução: A controvérsia sobre o declínio da empatia relativamente ao curso em estudantes de Medicina, Odontologia e Ciências da Saúde em geral ainda não foi completamente elucidada. Esta controvérsia poderia ser parcialmente solucionada se fossem realizados estudos significativos sobre os níveis de empatia em contextos culturais, sociais e económicos similares.

Material e Métodos: Foram estudados os níveis de empatía com o curso em dezoito escolas de Odontologia de seis países na América Latina (2013). As médias dos níveis de empatia foram usadas para estudar o comportamento entre académicos do primeiro e quinto anos. Os valores de níveis de empatia para com o curso foram observados aplicando a versão em espanhol da escala Jefferson de Empatia Médica. Todos estes estudos foram transversais. O valor das médias observadas sujeito a tratamento estatístico de regressão, obtendo-se as subsequentes curvas de ajustes e calculado o coeficiente de determinação.

Resultados: Foram observados seis diferentes modelos de comportamento, sendo que em cinco deles se verificou declínio da empatia, com diferentes resultados finais: em alguns, o declínio persistiu até o quinto ano académico e, em outros, o declínio 'recuperou-se' persistentemente até ao quinto ano académico. O sexto modelo caracterizou-se por um constante e persistente aumento nos níveis de empatia com o curso até o último ano académico.

Discussão: Existem seis modelos diferentes para o comportamento das médias dos níveis de empatia para com o curso, avaliados por uma metodologia comum em dezoito escolas de Odontologia de seis países na América Latina. Estes resultados suportam a existência de variabilidade de resposta empática, sendo necessária uma abordagem compreensiva para encontrar as suas causas.

1. Department of Biological Sciences. Facultad de Odontología. Universidad San Sebastián. Santiago. Chile

2. Department of Health Sciences. Faculty of Kinesiology. Universidad Bernardo O'Higgins. Santiago. Chile.

3. Department of Endodontist. Universidad Metropolitana. Barranquilla. Colombia.

4. Department of Educational Science. Facultad de Medicina. Universidad Libre Seccional Barranquilla y Fundación Universitaria San Martín. Barranquilla. Colombia.

5. Department of Investigación: Facultad de Odontología. Universidad de Cartagena. Cartagena. Colombia.

6. Herman Ostrow School of Dentistry. University of Southern California. Los Angeles. United States of America.

7. Department of Psychiatry. Felix Bulnes Hospital. Santiago. Chile.

8. Faculty of Dentistry. Universidad Nacional Pedro Henriquez Ureña. Santo Domingo. República Dominicana.

9. Department of Sociology. Instituto de Investigaciones Científicas. Universidad Central del Este. San Pedro de Macorís. República Dominicana.

10. Department of Dental Surgery. Facultad de Odontología. Universidad de Panamá. Panamá. Panamá.

11. Department of Health Sciences, Universidad Latinoamericana de Ciencia y Tecnología. San José. Costa Rica.

12. Department Nursing. Faculty of Health Sciences. Universidad del Tolima. Ibagué. Tolima. Colombia.

13. Department of Health Communication. Universidad del Tolima. Ibagué. Tolima. Colombia.

14. Department of Psychology. Faculty of Social Sciences. Universidad del Norte. Barranquilla. Colombia.

15. School of Medicine. Universidad Católica de Córdoba. Córdoba. Argentina.

$\square$ Autor correspondente: Víctor Patricio Díaz Narváez. vpdiaz@tie.cl

Recebido: 16 de janeiro de 2017 - Aceite: 02 de maio de 2017 | Copyright @ Ordem dos Médicos 2017 
Conclusão: Em estudantes de Odontologia da América Latina verifica-se variabilidade no comportamento da distribuição de meios entre os anos acadêmicos das escolas de odontologia examinadas neste trabalho.

Palavras-chave: América Latina; Empatia; Estudantes de Odontologia/psicologia

\section{INTRODUCTION}

It has been proposed, based on the results observed in various studies (longitudinal and cross-sectional), that empathy within the course in students of medicine, dentistry, nursing and kinesiology (among other health careers) 'suffers' a process that can be termed as 'empathic erosion' and is manifested by a decline in the values of empathy from the fourth year of the career. ${ }^{1-8}$ Empathic erosion starts occurring in the third year of the course,${ }^{9}$ which generally coincides with the change beginning in the area of basic preclinical or clinical sciences and, as a result, empathic decline is manifested in the remaining senior years with a relatively steady decline.

Some studies suggest that empathic erosion can be caused by direct contact with suffering and the student might respond as a natural reaction, a personal adjustment ${ }^{8}$ consisting of fatigue for compassion and professional burnout ${ }^{10,11}$ and implies a state of vulnerability for the development of stress disorders secondary to the profession. ${ }^{8}$ Ultimately, the processes which lead to erosion, could be influenced by various factors. Among them is the lack of time, personality type and anxiety towards patients, ${ }^{12,13}$ the lack of clinical mentors that can be role models as well, an intimidating educational environment, the perception of contempt, allocation of excessive educational and clinical tasks, and extenuating patients and negativity of the patients themselves, ${ }^{9}$ among other possibilities.

The scientific community studying empathy accepts the phenomenon of empathic erosion and, as described above, an important part of it indicates that the third year of the course is the turning point of the levels of empathy within the course and they begin to decrease in senior years. ${ }^{2,5,7-9,14}$ However, some studies have been published that contradict these results and show that this decline does not always occur, at least in absolute terms, ${ }^{16-18}$ all of which can be inferred that the empathic decline (as quantitative expression of erosion) seems not to be a 'scientific fact'..$^{15}$

Given the negative imprint that empathic erosion has on medical training and also given the disparity that exists in the literature about it, the objective of this investigation is to study the empathic behavior among courses from the first to fifth academic year of students from 18 dental schools in six countries in Latin America and verify whether these empirical results contribute to justify the fact that the empathic decline is a generalized behavior among students of dental schools.

\section{MATERIAL AND METHODS}

This investigation is exploratory, non-experimental, descriptive, cross-sectional and ex post facto cause and effect. Other authors published the data in this study. ${ }^{18-20}$ The study population consisted of students belonging to the courses from the first to fifth year of the undergraduate degree program of Dentistry of eighteen Dental Faculties in six countries in Latin America (Dominican Republic, Costa Rica, Panama, Colombia, Argentina and Chile) $(n$ total $=$ 4407). ${ }^{19-21}$

The Jefferson Scale of Physician Empathy (JSPE), the Spanish version for medical students (S), adapted and validated (for cultural form and content), specially for dental students in all the countries studied by criterion of judges, was applied to all students..$^{19-21}$

The primary and original data from the empathy levels within the course of each university examined were analyzed by the Cronbach's alpha test (reliability by internal consistency); the sum of the primary data score, obtained using the scale previously mentioned, were initially analyzed by the Kolmogorov-Smirnov normality test (K$\mathrm{S}$ ) in both types and to the Homoscedasticity Levene test and the effect size was measured by the Hedges $(\mathrm{g}) .^{18-22}$ The means of academic years, from first to fifth, in each of the universities were obtained from the aforementioned works ${ }^{18-20}$ and tested for polynomial regression to determine the type of curve an analysis of variance sequentially. In addition, the regression equation was estimated and the coefficient of determination $\left(R^{2}\right)$, were adjusted and unadjusted, associated with the estimated curve. Data was processed by the statistical program SPSS $20.0^{\circ}$ and Minitab $^{\odot}$. The significance level used was $\alpha \leq 0.05$ in each case.

\section{RESULTS}

The results of the estimates of means and the application of Cronbach a test, normality (K-S) and homoscedasticity (Levene) and Hedges ( $\mathrm{g}$ ) of the primary data were reported in the previous publications cited above, of which all of the associated statistical tests were satisfactory. ${ }^{19-21}$ In Table 1 the results of the application of regression to the mean values of empathy within the course of the five academic years studied in each of the universities examined are shown. It was found that most of means of the courses at the universities respond to a single type which was cubical, and only one university, a quadratic type (University of San Marcos, Peru).

From these results it can also be observed that there are six different trends of the means from the first to fifth academic year in the universities analyzed: A) steady growth of empathy (27.77\%); B) decreases in the fourth year, but increases in the fifth $(38.88 \%)$; $)$ increases until the third and then decreases and does not increase subsequently $(11.11 \%) ; D)$ increases in the fourth year and decreases in the fifth (5.55\%); E) decreases in the second, but increases in higher years $(11.1 \%)$ and $\mathrm{F}$ ) decreases from the first to third, but steadily increases in higher years $(5.55 \%)$. Of these six trends, $72.22 \%$ of the universities manifest an empathic decline within the course in some of the academic years. In relation to the total of universities studied those that 
Table 1 - Estimated value for the parameters of the distribution trend of the means from the first to fifth year's courses

\begin{tabular}{|c|c|c|c|c|c|}
\hline & Increase or decrease of empathy & $\mathbf{R}^{2}$ & $\mathbf{R}_{(\text {a) }}^{2}$ & F (ANOVA) & Equation \\
\hline \multirow[t]{6}{*}{ A) } & \multicolumn{5}{|l|}{ Constant increase of empathy $(27.77 \%$ of the total) } \\
\hline & A1. University of Fines Terrae (Chile) & 0.975 & 0.900 & $13.0(p=0.20)$ & $y=108.84+0.046 x^{3}-0.335 x^{2}+1.759 x$ \\
\hline & A2. University of Costa Rica (Costa Rica) & 0.944 & 0.775 & $5.589(p=0.299)$ & $y=114.08-0.471 x^{3}+4.448 x^{2}-9.801 x$ \\
\hline & A3. University Andrés Bello (Sede Santiago, Chile) & 0.982 & 0.927 & $17.94(p=0.171)$ & $y=111.5-0.32 x^{3}+2.69 x^{2}-4.914 x$ \\
\hline & A4. University Central del Este (República Dominicana) & 0.920 & 0.681 & $3.85(p=0.355)$ & $y=91.41-0.065 x^{3}+0.013 x^{2}-4.548 x$ \\
\hline & A5. Latin American University of Science and Technology (Costa Rica) & 0.999 & 0.997 & $412.9(p=0,056)$ & $y=94,236-0,128 x^{3}+0,336 x^{2}-4,385 x$ \\
\hline \multirow[t]{8}{*}{ B) } & \multicolumn{5}{|c|}{ Decrease in the fourth year, but increase in the fifth year ( $38.88 \%$ of the total) } \\
\hline & B1. University of Andrés Bello (Sede Viña del Mar, Chile) & 0.615 & 0.539 & $0.53(p=0.736)$ & $y=111.59-0.087 x^{3}+0.736 x^{2}-0.808 x$ \\
\hline & B2. Latin University of Panamá (Panamá) & 0.888 & 0.551 & $2.63(p=0.418)$ & $y=74.17-0.823 x^{3}-8.26 x^{2}+40.56 x$ \\
\hline & B3. University of Cartagena (Colombia) & 0.947 & 0.789 & $5.97(p=0.290)$ & $y=82.27+1.83 x^{3}-15.84 x^{2}+25.94 x$ \\
\hline & B4. University Metropolitana (Colombia) & 0.814 & 0.256 & $1.45(p=0.532)$ & $y=78.99+1.497 x^{3}-12.0 x^{2}+28.54 x$ \\
\hline & B5. University Peruana Cayetano Heredia (Perú) & 0.994 & 0.976 & $55.76(p=0.098)$ & $y=74.17-1.83 x^{3}-15.84 x^{2}+40.56 x$ \\
\hline & B6. Catholic University of Córdoba (Argentina) & 0.951 & 0.806 & $6.53(p=0.278)$ & $y=74.17-1.83 x^{3}-15.84 x^{2}+40.56 x$ \\
\hline & B7. University of Panamá (Panamá) & 0.711 & 0.156 & $0.82(p=0.650)$ & $y=79.31+1.104 x^{3}-11.86 x^{2}+36.03 x$ \\
\hline \multirow[t]{3}{*}{ C) } & \multicolumn{5}{|l|}{ Increase until the third and decrease after the fourth $(11.11 \%$ of the total) } \\
\hline & C1. University of Concepción (Chile) & 0.250 & 0.180 & $1.87(p=0.111)$ & $y=122.6-0.53 x^{3}+4.56 x^{2}-10.95 x$ \\
\hline & C2. University of Magdalena (Colombia) & 0.983 & 0.932 & $19.23(p=0.166)$ & $y=71.64+0.74 x^{3}-8.88 x^{2}+28.47 x$ \\
\hline \multirow[t]{2}{*}{ D) } & \multicolumn{5}{|l|}{ Increase until the fourth and decrease in the fifth $(5.55 \%$ of the total) } \\
\hline & D1. University San Martín (Colombia) & 0.752 & 0.090 & $1.01(p=0.607)$ & $y=115.62-1.74 x^{3}-14.05 x^{2}-30.41 x$ \\
\hline \multirow[t]{3}{*}{ E) } & \multicolumn{5}{|l|}{ Decrease in the second, but increase in the upper years $(11.11 \%$ of the total) } \\
\hline & E1. University of Antofagasta (Chile) & 0.897 & 0.587 & $2.89(p=0.402)$ & $y=78.02+1.03 x^{3}-9.964 x^{2}+30.849 x$ \\
\hline & E2. University of Desarrollo (Chile) & 0.639 & 0.442 & $0.59(p=0.716)$ & $y=111.59+0.266 x^{3}-2.355 x^{2}+5.52 x$ \\
\hline \multirow[t]{2}{*}{ F) } & \multicolumn{5}{|c|}{ Decrease from the first to third and then a constant increase until the fifth $(5.55 \%$ of the total) } \\
\hline & F1. National University Mayor de San Marcos* & 0.992 & 0.984 & $120.95(p=0.08)$ & $y=117.27+1.154 x^{2}-6.83 x$ \\
\hline
\end{tabular}

showed a decline, and at the same time, were in strict accordance with the distribution of means of empathy posed by Hojat et al, ${ }^{9}$ the value was $16.66 \%$ (cases $\mathrm{C}$ and D). Also, of the total, $55.54 \%$ had an empathic decline; but this decrease is interrupted by a steadily increase of the empathy value of the means until the end of the course (cases B, E and F) (Table 1).

In most cases, the $\mathrm{R}^{2}$ values explain well the variation of means in the years studied (values $\geq 0.40$ ), with the exception of the Metropolitan University (0.256, Colombia); University of Panama (0.156, Panama); University of Concepción (0.18, Chile) and Universidad San Martín (0.09, Colombia). However, these values do not affect the general trends estimated for these universities. When ANOVA results were not significant $(p>0.05)$, this implied a type of curve that best matched the data of the distribution of means, all of which allowed estimation of the corresponding regression equation (Table 1). For example, Fig. 1 shows the graphical results of the University of Costa Rica (Costa Rica) (Table 1: A2), with a steady increase in the means of the academic years, of six of the universities studied were classified as 'A'; in Fig. 2 the graphical results of the University of Cartagena (Colombia) (Table 1: B3) are shown, which shows an increase until the third year, a decrease in the fourth and once again an increase in the fifth year; in Fig. 3, the graphic results of the University of
Magdalena (Colombia) (Table 1: C2) are shown, which showed an increase until the third year and, subsequently, a decrease in the remaining academic years; finally, at the University of San Marcos (Peru) (Table 1: F1) a decrease was observed from the first to the third academic year and then sustained growth in the remaining years. For reasons of space, the present article does not present all the graphs of all the universities studied.

\section{DISCUSSION}

The six trends demonstrate the existence of variability in the distribution of means of the empathic response in the different academic years examined from dental school students of different universities in Latin America. The variability of the empathic response has also been previously observed, by other authors, in the gender variable in students of Dentistry ${ }^{19-22}$ and Medicine. ${ }^{23}$ The results observed in this study are consistent with those obtained by the authors mentioned above in terms of the existence of variability of empathic response that seems to be a rule rather than an exception ${ }^{22-28}$ and shows the existence of different models for presentation of the means of empathy within the course estimated in consecutive academic years. As a result, variability occurs with empathic decline in different years of the course (not limited only to the third year). We also find models that have no decline, but a 


\section{Fitted line plot}

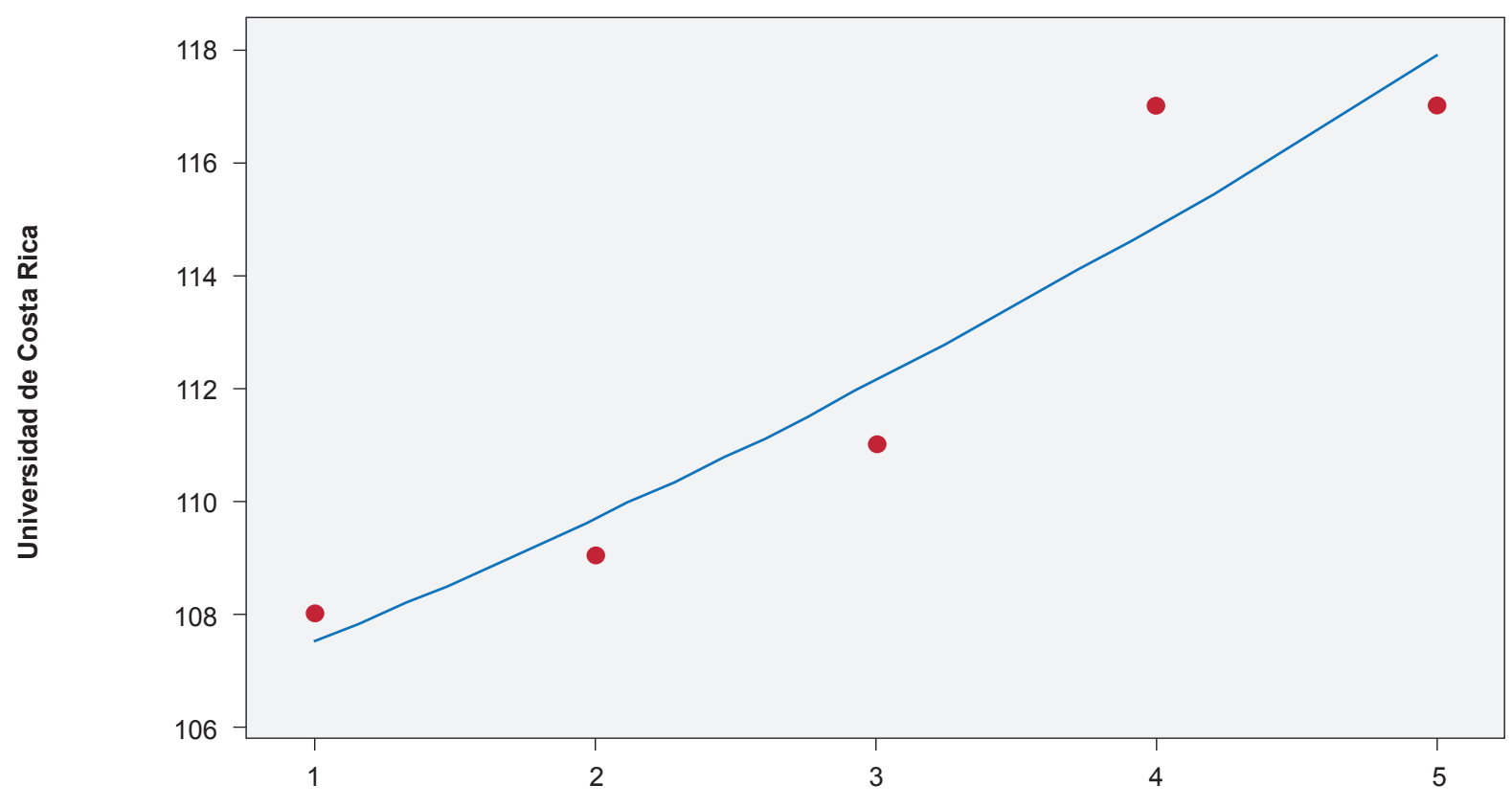

Academic course

Figure 1 - Cubic regression model of the Faculty of Dentistry at the University of Costa Rica (San Jose, Costa Rica)

Fitted line plot

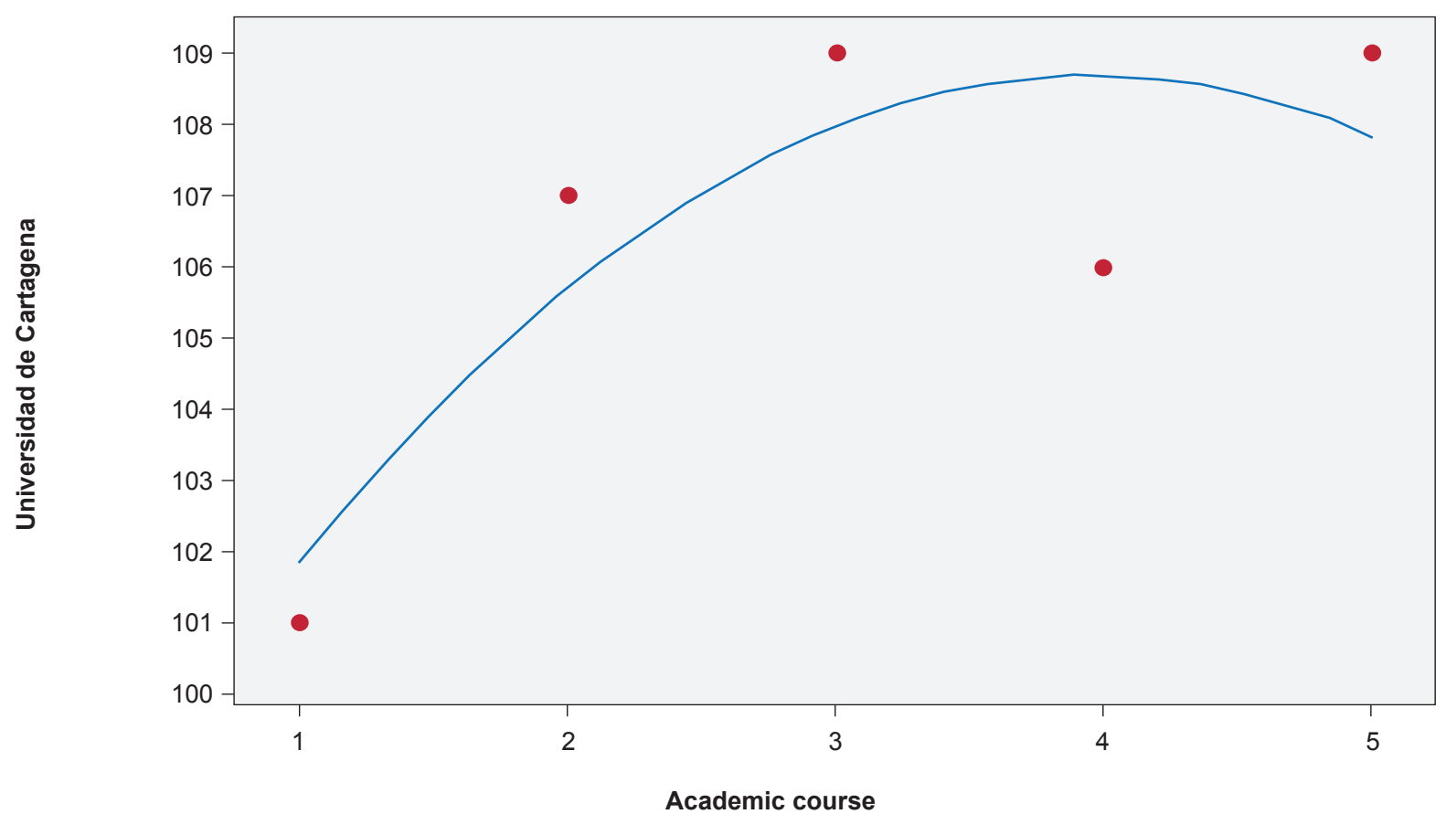

Figure 2 - Cubic regression model of the Faculty of Dentistry at the University of Cartagena (Cartagena, Colombia)

steady increase in levels of empathy within the course and, therefore, an absence of empathic erosion. The presence of sustained empathic decline, therefore, from the fourth academic year onwards is not a generalized phenomenon, but rather a finding of particular character. The consistency of the findings in this paper about the presence of different presentation models of empathic decline is based on the use of the same instrument to measure empathy, whose characteristics has been summarized by Hojat et $a^{\rho}$ and applied the same statistical estimation processes by the statisticians. Biases, therefore, that may exist will have the same characteristics in all estimates of the means of the 
Fitted line plot

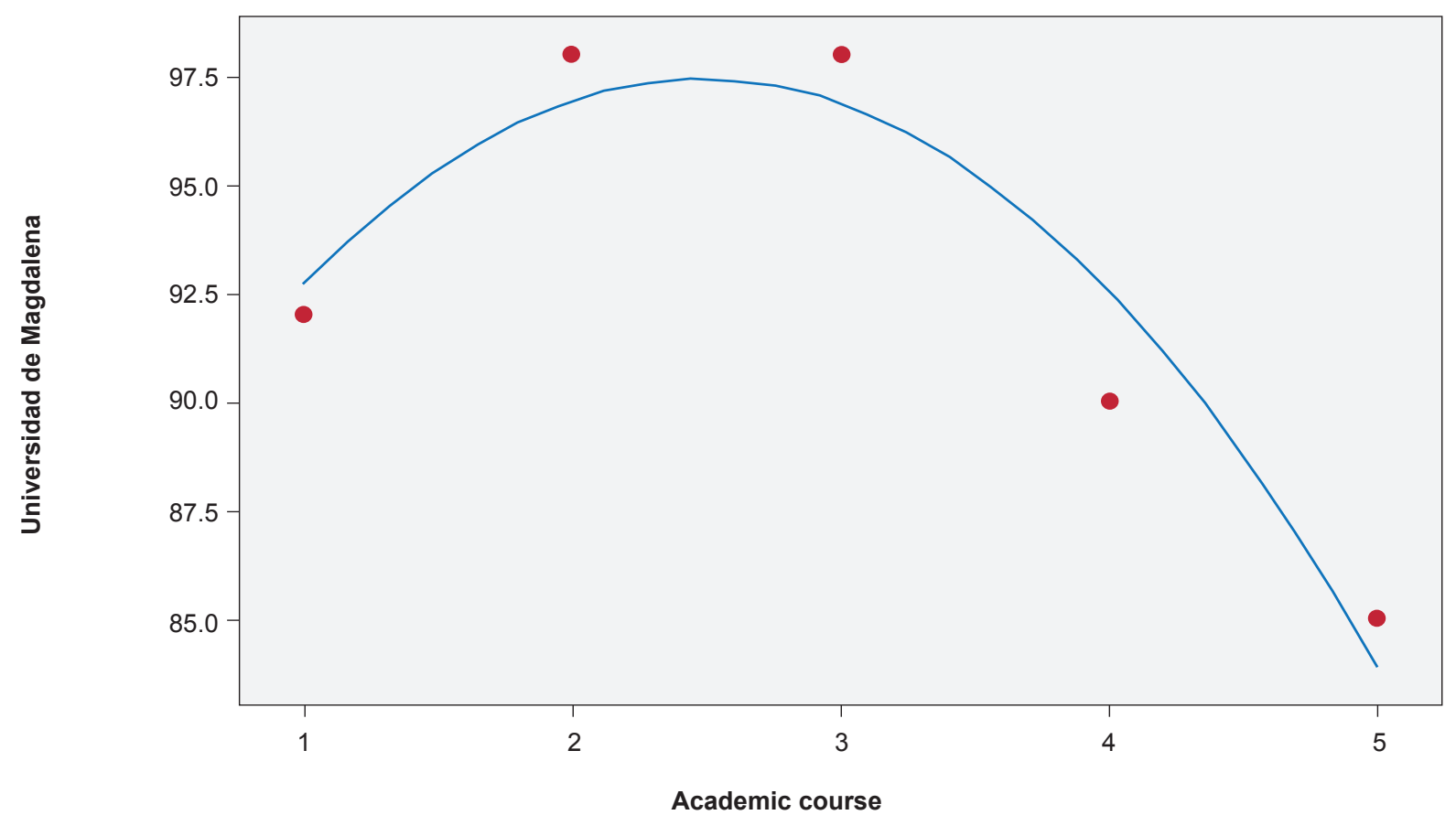

Figure 3 - Cubic regression model of the Faculty of Dentistry at the University of Magdalena (Santa Marta, Colombia)

Fitted line plot

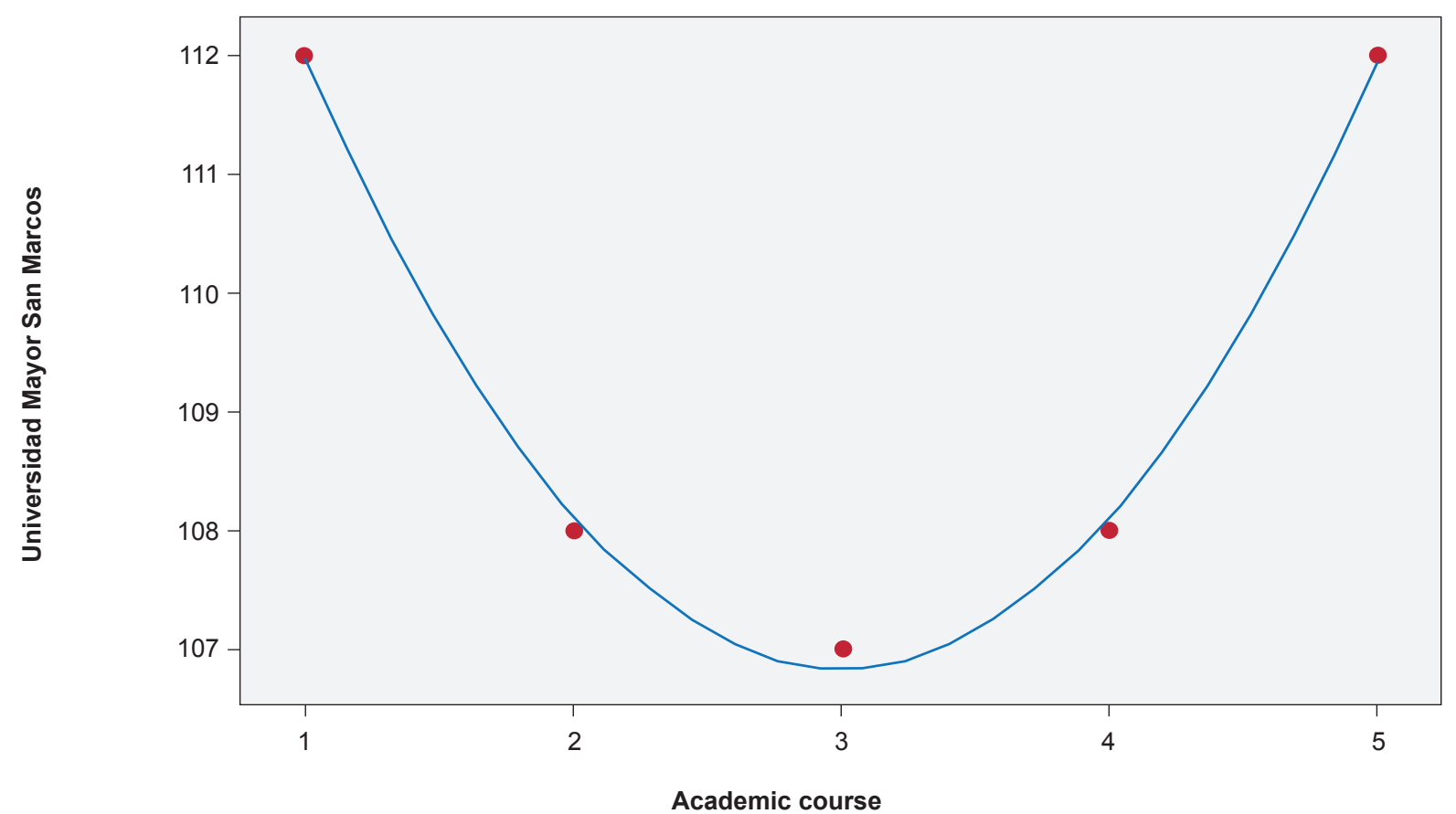

Figure 4 - Cubic regression model of the Faculty of Dentistry at the University Mayor de San Marcos (Lima, Peru)

courses studied in each university.

As for the regression curves found in this study, it is possible to note that only in universities of Group C: Magdalena (Colombia) and Concepcion (Chile) the value of the means of empathy increases until the third year and then decrease steadily, are the only ones that coincide with those works that have raised a decline of empathy from third year. ${ }^{1,2,7,9,29-31}$ A similar situation occurs in the University of San Martin (Colombia) that grows until the fourth and then decreases in the fifth year (group D). The other dental schools, with the exception of group A, suffer a decline in some of the early years, but then a steadily increase of 
empathy occurs within the course in the higher years.

These findings, rather than help categorize variation of empathy within the course between academic years in a particular university (dental schools), shows that the phenomenon of empathy is very complex in terms of: a) the presence of certain factors that may be necessary causes, but not enough to finally produce empathic decline; b) the existence of other factors that favorably affect the ability to develop empathy and, finally, c) in some cases certain interventions that might have positively changed the empathic response.

In fact, the work done within those universities, where there was a steady increase in the means (Table 1, Group A), raised practically a common denominator: a) an approach to teaching and learning from a comprehensive perspective; b) adequate preparation of students in the pathophysiological aspect and practical skills, as well as from the point of view of interpersonal relationships, to achieve confrontation with the patient with proper emotional balance ${ }^{32}$; c) humanistic orientation of the career and the existence of systematic awareness activities throughout the entire course of studies, considering education centered on the human being and the humanistic or classic formation took into consideration the mind, social being, emotions and skills necessary for a career ${ }^{33}$; d) the application of a mixed model prepares students for society and culture ${ }^{25} ; \mathrm{e}$ ) offer courses from the first year in the field of dental science and, with this, ensure that the student begins to think of the patient as an ideal potential relationship and those, in higher levels, employ $84 \%$ of their time in dental care both inside, as well as outside the university, in clinics of underprivileged communities (community participation in health), all of which, can deepen relationships and the reality of patients for which they can be treated comprehensively acquiring a sense of responsibility and commitment to them. ${ }^{34}$

In relation with universities grouped in C and D (Universidad de Concepcion, Chile; Magdalena University, Colombia and Universidad San Martin, Colombia) suggest that the possible causes of empathic decline within the course in academic years higher then the third could be because: a) involvement with patients and assuming direct responsibilities with them and $b$ ) the stress produced by the aforementioned responsibility. ${ }^{3,35}$ In case of the group of universities designated as $B$ and $E$ (Table 1), these point as possible causes of increase in fourth year (in general): a) the organization of rotations in different areas of the clinic, which allows the student to gradual develop healthcare skills that allow decisions; b) during the first two years of the career initiates approaches with patients under the concept of 'Primary Health Care' which focuses on management of clinical situations under controlled conditions and with a progressive delegation of activities within the city, as well as rural areas that extent through higher courses; c) direct responsibilities with the patient from the second year of the career and direct responsibility from the fourth year under a biopsychosocial approach, d) socio-humanistic formation under community competence, e) the offer of programs with emotional and cognitive components, which could have influenced the communication skill for successful human relations. ${ }^{25,36-38}$ Finally, at the National University of San Marcos (Peru) (Case E), the sustained increase found in the fourth and fifth year is explained mainly by the influence of teachers or models that are observed by students in their preparation stage in the clinical area. ${ }^{24}$

Empathic erosion in medical students and other areas of medical education is an objective fact which is conditioned by many causes, which have been, described elsewhere, ${ }^{5,7-10,29,31}$ but is not a general phenomenon. ${ }^{16-18,39,40}$ The importance of the findings in this research is that it poses a dilemma of whether or not there exists empathic decline within the course, and need to determine and measure what are the root causes of this decline and, above all, respond to the finding that it occurs in some of the universities studied and not in others. Furthermore, we must explain why the empathic decline is not only evident in one turning 'point': the third academic year, but in different academic years with values of empathy, which grew in some cases and, in others declined.

As a result, an approximation of the explanation of the variability observed in this study is that this attribute has many different sources of variation. In general, they can be: a) statistics: the effect of the sample size, the nature of the values, or type of statistical designs used; b) that the instruments used to measure empathy may contain underlying 'variables'; c) differences in the degree of internal reliability found, as well as differences in the way of finding validity, from the concept we have empathy construct; d) the teaching and educational measures that the university may or may not implement to students in relation to the formation of empathy and, finally (without exhausting other possibilities); e) differences may exist in those biopsychosocial factors in the environment which has developed the future student in dentistry or health sciences in general and influencing the conformation of the active structure and dynamics of empathy on the subject before even going to study in a university and how this structure can influence the possible development of empathy in the teaching-learning process of a medical student. All these factors, if not controlled (as far as possible) will produce biases in the evaluation of empathy within the course, which can contribute to the finding of 'no significant difference' or 'significant differences' which may exist or not respectively. However, what is important, we agree with Hojat et al. ${ }^{9}$ in that the most important task for all institutions involved in the formation of empathy is to ensure that it is developed as much as possible, before and during, the process of training of students of health sciences in general, so that it is not affected by the factors that determine or contribute to decline of the values of empathy within the course. We also agree with Roff, ${ }^{17}$ who suggests, in general, complex models combining the integration of several factors that allow the understanding of empathy are required for better patient care.

This study has, however, some limitations: a) it is a 
cross-sectional study that does not permit the assessment of the same subject over time; b) partial generalizations made in this work is only valid for dental students in Latin America and c) similar studies are required of students from other healthcare fields, to verify that the behavior of empathy within the course in Latin America is similar in all healthcare fields.

\section{CONCLUSION}

In dental students of Latin America there is variability in the behavior of the distribution of means between the academic years of the dental schools examined in this study. Six distinct models were found. These models show that: a) empathic decline within the course reaches its turning point in different academic years and with sustained increase or decrease in different results after the turning point was observed; therefore there are different models of empathic decline; b) there are models in which a consistent distribution is expressed in the sustained increase in levels of empathy within the course, which, theoretically, show that empathic erosion is not present and c) more complex studies are required to understand the process of the formation of empathy with the course in dental students, in particular, and health sciences, in general.

\section{PROTECTION OF HUMANS AND ANIMALS}

The authors declare that the procedures were followed according to the regulations established by the Clinical Research and Ethics Committee and to the Helsinki Declaration of the World Medical Association.

\section{DATA CONFIDENTIALITY}

The authors declare having followed the protocols in use at their working centers regarding patients' data publication.

\section{CONFLICTS OF INTEREST}

All authors report no conflict of interest.

\section{FUNDING SOURCES}

This research received no specific grant from any funding agency in the public, commercial, or not-for-profit sectors.

\section{REFERENCES}

1. Chen D, Lew R, Hershman W. A cross-sectional measurement of medical student empathy. J Gen Intern Med. 2007;22:1434-8.

2. Sherman J, Cramer A. Measurement of changes in empathy during dental school. J Dental Educ. 2005;69:338-45.

3. Bilbao JL, Iglesia JE, Díaz-Narváez VP, Crespo-Camacho E, Alonso LM, Alcocer A. Empathic guidance in medical student of the Universidad Libre and San Martín, Barranquilla, Colombia. Rev Fac Med. 2015;63:237-45.

4. Rojas AM, Castañeda-Barthelemiez S, Parraguez-Infiesta RA. Empathetic orientation of the physical therapist's students from two schools of Chile. Educ Med. 2009;12:103-9.

5. Moreto G, González-Blasco P, Pessini L, Croice-de-Benedetto MA. Empathy erosion of medical students: report of a study conducted in one medical school in Sao Paulo, Brazil. Atem Fam. 2014;21:16-9.

6. Newton BW, Barber L, Clardy J, Cleveland E. Is there hardening of the heary during medical school? Acad Med. 2008;83:934-41.

7. Hojat M, Mangione S, Nasca TJ, Rattner S, Erdmann JB, Gonnella JS, et al. An empirical study of decline in empathy in medical school. Med Educ. 2004;38:934-41.

8. Galán JM, Romero R, Morillo MS, Alarcón M. Descent of empathy in nursing students and analysis of possible factors involved. Psicol Educ. 2014;20:53-60.

9. Hojat M, Vergare MJ, Maxwell K, Brainard G, Herrine SK Isenberg GA, et al. The devil is in the third year: a longitudinal study of erosion of empathy in medical school. Acad Med. 2009;84:1182-91.

10. Figley CR. Compassion fatigue: psychotherapist's chronic lack of self care. J Clin Psychol. 2002;58:1433-41.

11. Decety J, Lamm C. Human empathy through the lens of social neuroscience. Sci W J. 2006;6:1146-63.

12. Reynolds W, Scott Pa, Austin W. Nursing, empathy and perception of the moral. J Adv Nurs. 2000;32:235-42.

13. Price V, Archbold J. What's it all about empathy? Nurse Educ Today. 1997;17:106-10.

14. Hojat M, Gonnella JS, Veloski J. Rebuttals to critics of studies of the decline of empathy. Acad Med. 2010;85:1812.

15. Díaz-Narváez VP, Calzadilla A, López H. An approach to the concept of scientific fact. Cinta Moebio. 2005;22:100-11.

16. Colliver JA, Conlee MJ, Steven J, Dorsey JK. Rebuttals to critics of studies of the decline of empathy. Acad Med. 2010;85:1813-4.

17. Roff S. Reconsidering the 'decline' of medical student empathy as reported in studies using the Jefferson Scale of Physician EmpathyStudent version (JSPE-S). Med Teach. 2015;10:1-4.

18. Costa $\mathrm{P}$, Magalhaes $\mathrm{E}$, Costa MJ. A latent growth model suggests that

empathy of medical student does not decline over time. Adv Health Sci Educ. 2013;18:509-22.

19. Díaz-Narváez VP, Gutierrez-Ventura F, Varela T, Salcedo-Rioja M, Calzadilla-Nuñez A, Hamdan-Rodriguez M, et al. Empathy levels of dentistry students in Peru and Argentina. Health. 2015;7:1268-74.

20. Díaz-Narváez VP, Erazo AM, Bilbao JL, González F, Padilla M, Howard $M$, et al. Empathy levels of dental students of Central America and the Caribbean. Health. 2015;7:1678-86.

21. Díaz-Narváez VP, Calzadilla A, Carrasco D, Bustos A, Zamorano A, Silva $\mathrm{H}$, et al. Levels of empathy among dental students in five Chilean universities. Health. 2016;8:32-41.

22. Díaz-Narváez VP, Erazo AM, Bilbao JL, González F, Padilla M, Howard $\mathrm{M}$, et al. Empathy gender in dental students in Latin America: an exploratory and cross-sectional study. Health. 2015;7:1527-35.

23. Díaz-Narváez VP, Alonso LM, Caro SE, Silva MG, Arboleda J, Bilbao $\mathrm{JL}$, et al. Empathic orientation among medical students from three universities in Barranquilla, Colombia and one university in Dominican Republic. Arch Argent Pediatr. 2014;112:41-9.

24. Salcedo MR, Díaz-Narváez VP. Empathy in dental students of National University of San Marcos. Salud Uninorte. 2015;31:465-74.

25. Silva MG, Arboleda J, Díaz-Narváez VP. Empathic orientation of dental students of the Universidad Central del Este. Odontoestomatología. 2013;22:24-33.

26. Erazo AM, Alonso LM, Rivera I, Zamorano A, Díaz-Narváez VP. Measurement of Empathic Orientation in dentistry students of Metropolitana University of Barranquilla (Colombia). Salud Uninorte. 2012;28:354-63.

27. Silva MG, Arboleda J, Díaz-Narváez VP. Empathic orientation observed in medical students at one university in the Dominican Republic. Educ Med Sup. 2014;28:74-83.

28. Huberman J, Rodríguez MP, González S, Díaz-Narváez VP. Empathetic orientation levels in odontology students of the Universidad del Desarrollo, sede Santiago (Chile). Rev Clin Periodoncia Implantol Rehabil Oral. 2014;7:169-74.

29. Nunes P, Williams S, Sa B, Stevenson K. A study of empathy decline in students from five health disciplines during their first year of training. Int J Med Educ. 2011;2:12-7.

30. Tavakol S, Dennick R, Tavakol M. Empathy in UK medical students: differences by gender, medical year and specialty interest. Educ Primary Care. 2011;22:297-303.

31. Vahid S, Habibi M. Empathy in Iranian medical students: measurement model of the Jefferson Scale of Empathy. Med Teacher. 2013;35:e9138. 
32. Silva H, Rivera I, Zamorano A, Díaz-Narváez VP. Evaluation of empathetic orientation in dentistry students of Finis Terrae University in Santiago, Chile. Rev Clin Periodoncia Implantol Rehabil Oral. 2013;6:130-3.

33. Howard M, Navarro S, Rivera I, Zamorano A, Díaz-Narváez VP. Measuring the level on empathic orientation in the student of the Faculty of Dentistry, University of Costa Rica. Odontos. 2013;15:21-29.

34. Sánchez L, Padilla M, Rivera I, Zamorano A, Díaz-Narváez VP. Evaluation of empathetic orientation in odontodology students. Educ Med Sup. 2013;27: 216225.

35. Carrasco D, Bustos A, Díaz V. Empathetic orientation of Chilean dental students. Rev Stomatol Herediana. 2012;22:145-51.

36. Varela TB, Villaba HR, Gargantini P, Quinteros S, Villalba SB, DíazNarváez VP. Levels of empathic orientation in dentistry students of the Catholic University of Córdoba, Argentina (UCC). Claves Odontol.
2012;70:15-22

37. Bullen M, Salazar L; Díaz-Narváez VP. Empathic orientation of denta students from University of Panama (Republic of Panama). Salud Uninorte. 2015;31:253-62.

38. González-Martínez FD, Díaz-Narváez VP, Arrieta-Vergara K, DíazCárdenas S, Tirado-Amador LR, Madera-Anaya M. Distribution of empathetic orientation among dentistry students of Cartagena, Colombia. Rev Salud Publica. 2015;17:404-15.

39. Bangash AS, Ali NF, Shehzad AH, Haqqi S. Maintenance of empathy levels among first and final year medical students: a cross sectional study. F1000 Res. 2014;2:157-65.

40. Shankar PR, Piryani RM. Changes in empathy among first year medical students before and after a medical humanities module. Educ Med J. 2013;5e35-e40. 